\title{
The development of the Pictish symbol system: inscribing identity beyond the edges of Empire
}

Gordon Noble $^{1, *}$, Martin Goldberg ${ }^{2} \&$ Derek Hamilton $^{3}$

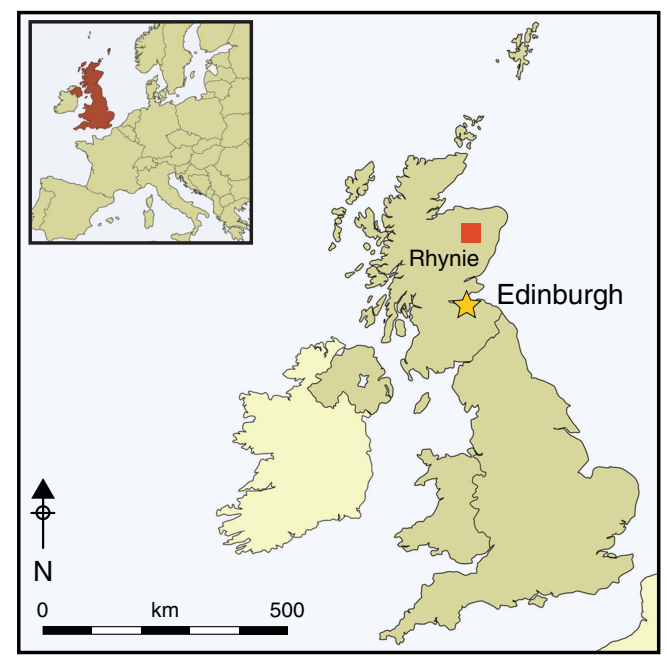

The date of unique symbolic carvings, from various contexts across north and east Scotland, has been debated for over a century. Excavations at key sites and direct dating of engraved bone artefacts have allowed for a more precise chronology, extending from the thirdlfourth centuries $A D$, broadly contemporaneous with other non-vernacular scripts developed beyond the frontiers of the Roman Empire, to the ninth century $A D$. These symbols were probably an elaborate, non-alphabetic writing system, a Pictish response to broader European changes in power and identity during the transition from the Roman Empire to the early medieval period.

Keywords: Scotland, Pictish, symbolism, carving, language, writing

\section{Introduction}

The origins and evolution of writing are one of the most critical and transformative developments in world history (Innes 1998: 3). Writing revolutionises the forms and possibilities of communication, and has been linked directly to state formation in many different social and chronological contexts across the world (e.g. Goody 1968: 4; Baines 1995: 471; Postgate et al. 1995: 459; Papdopoulos 2016: 1252). In Northern Europe, the alphabetic systems of the Greeks, and Etruscan and Roman derivatives in the west, inspired new forms of writing, with vernacular scripts developing on the fringes of the Roman Empire

1 Department of Archaeology, School of Geosciences, University of Aberdeen, St Mary's, Elphinstone Road, Aberdeen $A B 243 U F, U K$

2 Department of Scottish History and Archaeology, National Museums Scotland, Chambers Street, Edinburgh EH1 1JF, UK

3 Scottish Universities Environmental Research Centre, University of Glasgow, Rankine Avenue, East Kilbride G75 OQF, UK

* Author for correspondence (Email: g.noble@abdn.ac.uk)

(C) Antiquity Publications Ltd, 2018 This is an Open Access article, distributed under the terms of the Creative Commons Attribution licence (http://creativecommons.org/licenses/by/4.0/), which permits unrestricted reuse, distribution and reproduction in any medium, provided the original work is properly cited.

ANTIQUITY 92365 (2018): 1329-1348

https://doi.org/10.15184/aqy.2018.68 
in the first millennium AD. These included the runic system of Scandinavia and north Germany, and the ogham alphabet of Ireland and western Britain (e.g. Swift 1997; Barnes 2012; Findell 2014). Both of these scripts were used across early medieval Britain and Ireland, but the most common and monumental form of communication that survives from northern Britain is the less well-understood Pictish symbol system. Strong arguments have been made that this symbol system is also a script, albeit un-deciphered (Samson 1992; Forsyth 1997; Lee et al. 2010). Debate over its origins and dating have continued for over a century, and here we present the results of a new programme of radiocarbon dating and Bayesian modelling on a range of new sites and objects to provide a more robust chronology for the development of Pictish symbols, pointing to an earlier origin than many scholars have previously countenanced.

\section{The Picts and their symbols}

The Picts are first mentioned in AD 297 in a Latin panegyric (Panegyrici Latini 8.20. 4-5; Nixon et al. 1994) that was written in praise of a late Roman Emperor, and the Latin term Picti was then used in late Roman sources throughout the fourth century AD in the context of attacks on the Roman frontier (Fraser 2009: 43). In a post-Roman context, the Picts are referenced in early medieval Latin and vernacular sources by their neighbours, with the only historical sources that can be attributed to the Picts themselves being a problematic set of king-lists preserved in much later medieval manuscripts (Woolf 2007). The archaeological evidence for the Picts also presents some difficulties: compared with a rich Iron Age record, few settlements are known and artefact chronologies are poor (Driscoll 2011; Foster 2014). The so-called Pictish symbol-stones, however, represent an iconic element of the archaeological record—sculptured stones carved with distinctive symbols, some abstract, others naturalistic, including striking animal designs or objects such as mirrors and combs (Henderson \& Henderson 2004: 167). The symbol-stones have long been identified as Pictish because their distribution closely matches the extent of the Pictish kingdoms as reconstructed from the limited historical sources and from place-names (Wainwright 1955: 43) (Figure 1).

There are over 200 stone monuments with symbols known from eastern and northern Scotland (RCAHMS 2008) — approximately two-thirds are incised symbol-stones, and the other third are Christian cross-slabs (Figure 2). The symbols also occasionally appear on metalwork, bone and other portable objects. There is little agreement about the total number and range of symbols, but around 30 core symbols have been suggested (Samson 1992: 37; Forsyth 1997: 87). There have been repeated attempts to decipher the meaning of the symbols since the nineteenth century (Table $S 1$ in the online supplementary material), with wide-ranging interpretations, including icons of pagan or Christian religion (e.g. the Earl of Southesk 1893; Allen \& Anderson 1903 [1993]), symbols of rank or tribal identity (Diack 1944; Thomas 1963; Henderson 1967), symbols of marriage alliances (Jackson 1984) and memorials to the dead (Laing \& Laing 1984; Driscoll 1988; Mack 2007), as well as countless 'fringe' ideas and speculation.

Current consensus suggests that the symbol system was a form of script, albeit undeciphered, and part of broader trends of experimentation with writing at the northern

(C) Antiquity Publications Ltd, 2018 


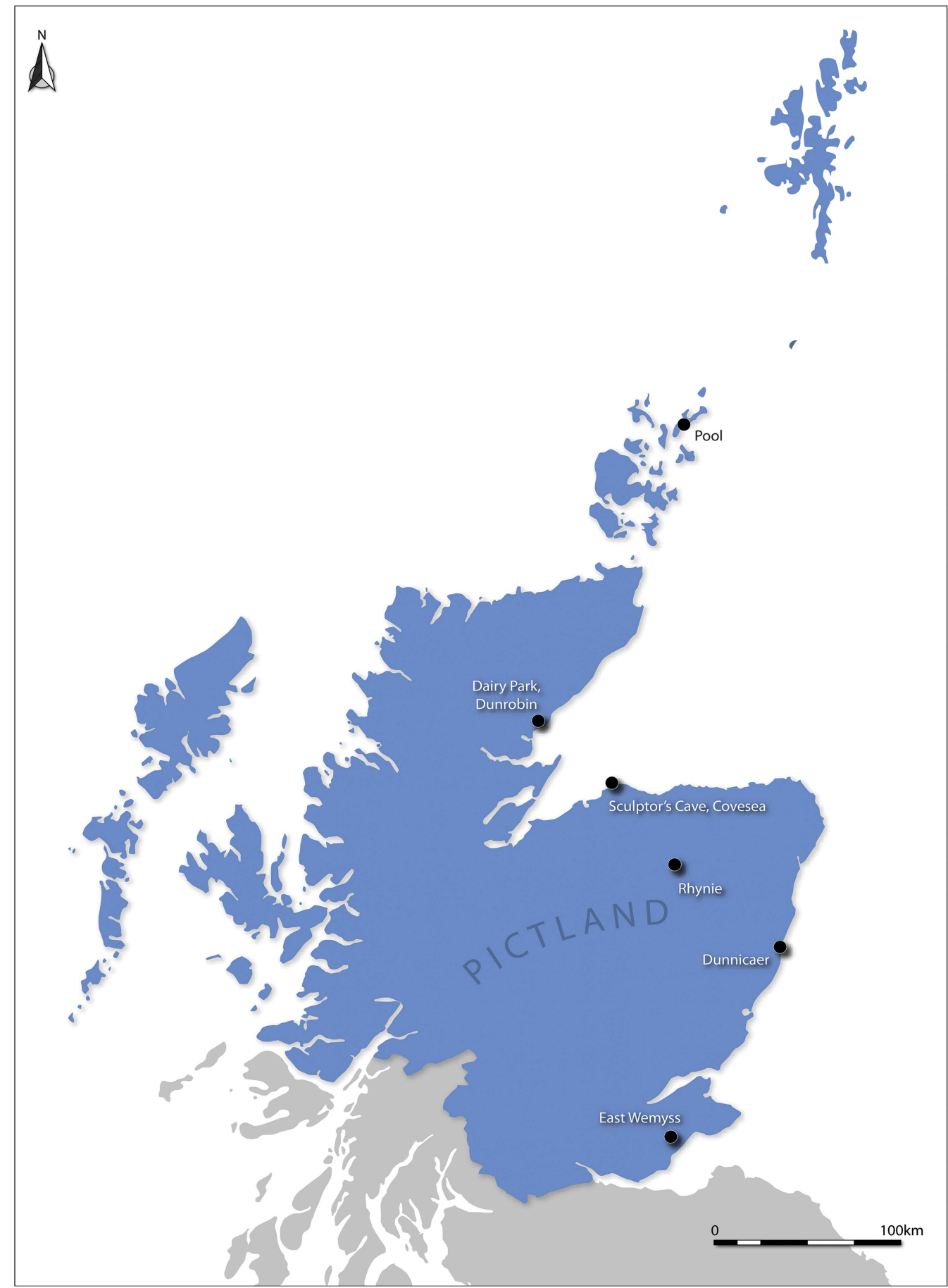

Figure 1. Location of the main sites discussed in the text. The probable maximum extent of Pictland is also highlighted in blue and overlain on the modern outline of northern Britain (@) Crown Copyright/database 2018. An Ordnance Survey/EDINA supplied service). 
Gordon Noble et al.
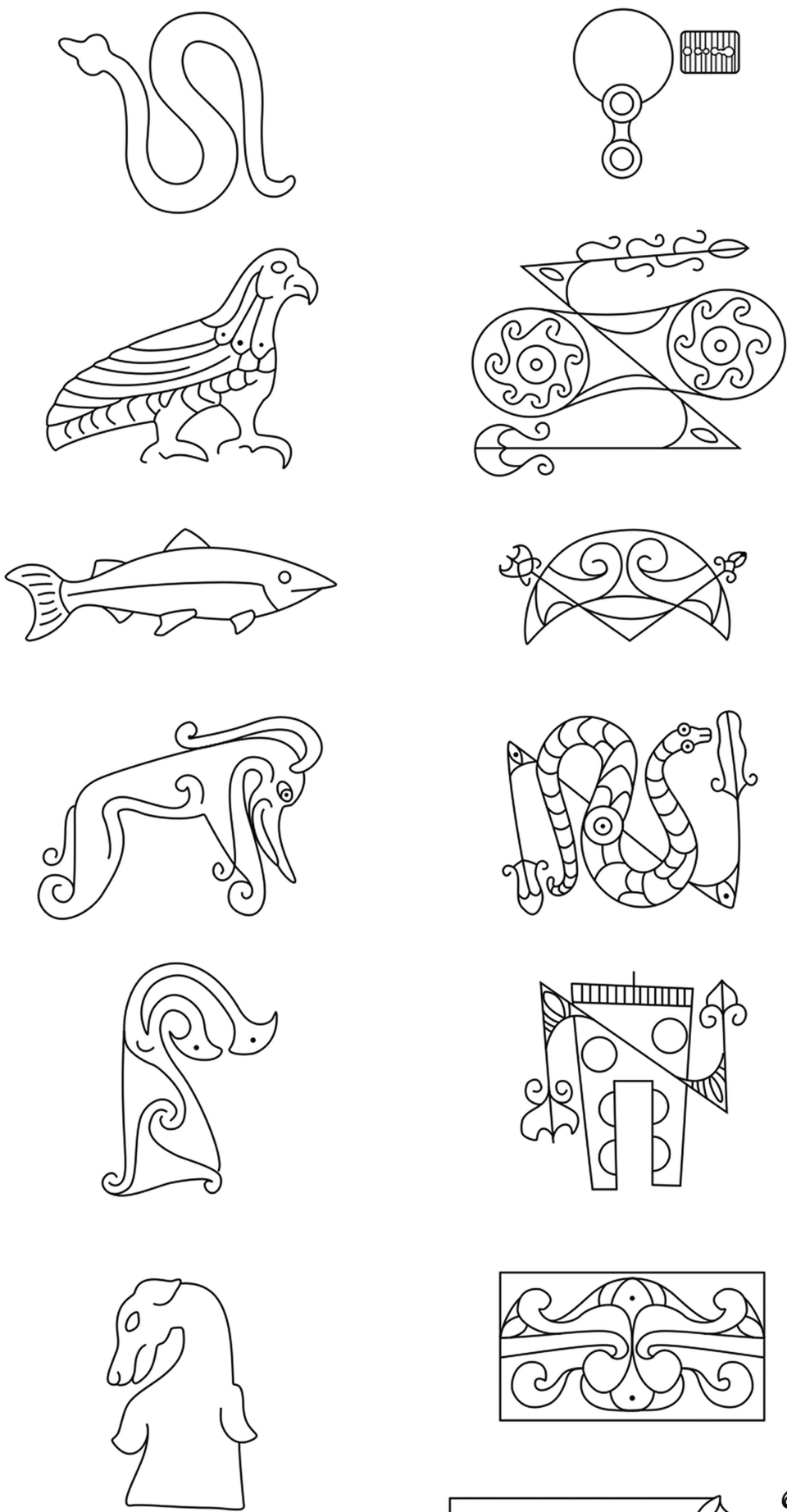

Figure 2. Examples of Pictish symbols (after RCAHMS 2007).

(C) Antiquity Publications Ltd, 2018 


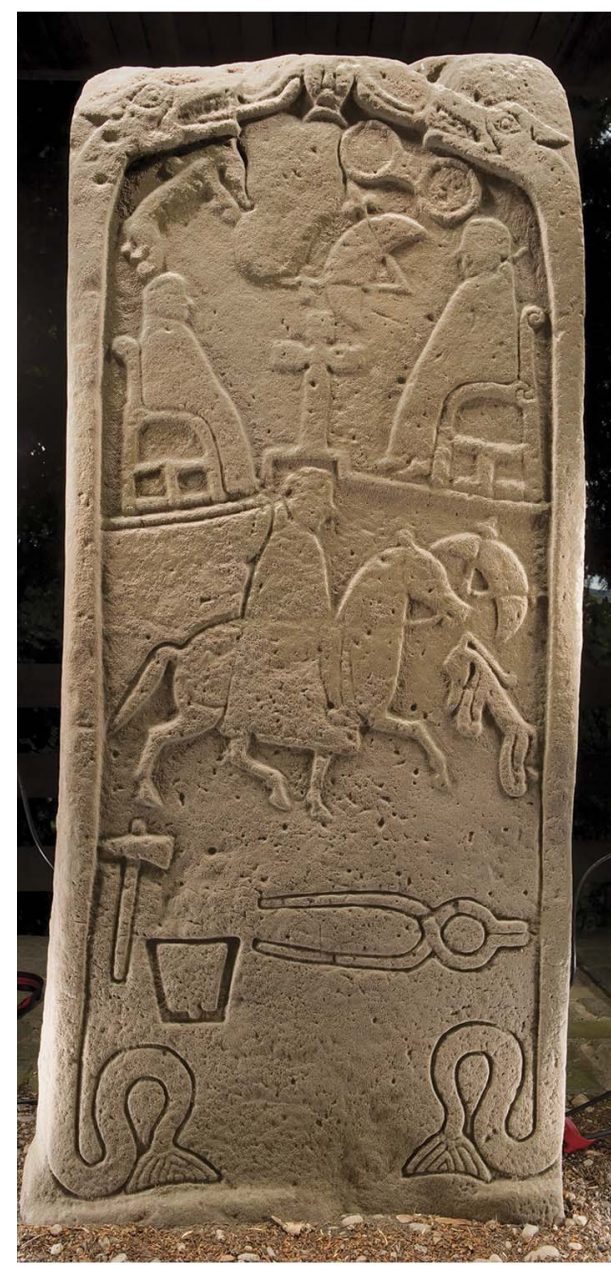

Figure 3. The Dunfallandy stone, Perthshire. The people depicted are 'labelled' with symbols: the figure in the upper left has a single symbol only (although note that the stone surface here is unfinished, perhaps leaving space for a second symbol), while the figure to the right and the mounted individual are next to symbol pairs (C) Crown Copyright: HES). fringes of the Roman Empire. The roots of this research lie with Samson (1992), who saw the common pairing of symbols as key to interpretation, arguing that the symbols did not work in isolation, but that the recurrent symbol pairs worked together to represent personal names-perhaps two elements of a dithematic name, that is, the symbols represent a written version of a language rather than abstract ideas. Forsyth also identified symbol pairs as "the fundamental syntax" of the Pictish symbol system (1997: 87), and more recent work applying statistical analysis has supported the interpretation of the symbols as a written language (Lee 2010; Lee et al. 2010; although see Sproat 2010). A naming system is also suggested by some specific monuments; for example, on the back of a cross-slab from Dunfallandy, Perthshire, two seated figures and a mounted individual are shown with symbol pairs directly adjacent. The close juxtaposition of symbols with human figures can also be identified on other monuments (Figure 3) (Allen \& Anderson 1903 [1993]: 38; Stevenson 1955: 123). While the symbols probably communicated names, as is common in the runic and ogham systems, the Pictish symbols were not an alphabetic script and this has perhaps contributed to the 'othering' of the Picts (see Alcock 2003: 373).

\section{Dating the symbol tradition}

Over a century ago, the seminal volume The Early Christian monuments of Scotland (Allen \& Anderson 1903 [1993]) set out a typological classification that is still used widely to the present day. Class I monuments (incised symbols usually on unshaped boulders) were assigned to the seventh to eighth centuries AD, and Class II monuments (where symbols appear with a much broader repertoire of ornamental, narrative scenes and a Christian cross) to the ninth and tenth centuries $\mathrm{AD}$. This chronology has remained popular throughout the twentieth century (Table S1). Charles Thomas (1961) related certain symbols to Late Iron Age art styles, and consequently suggested a fifth-century start date for the simpler Class I designs, a scheme followed by Laing and Laing (1984, 1993).

(C) Antiquity Publications Ltd, 2018 
Nonetheless, chronology remains controversial, and previously there was no direct dating that demonstrated the use of the symbols prior to the late sixth century (Clarke \& Heald 2008); suggestions of earlier dates were based entirely on art-historical analysis rather than absolute or contextual dating.

\section{Establishing a new chronology}

The major obstacle to establishing a definitive chronology is the difficulty of obtaining absolute dates from stone monuments. It has been necessary therefore to rely on contextual dating, such as dates from human remains found in association with the Class I symbol-stone at Dairy Park, Dunrobin, Sutherland (Close-Brooks 1980). This was found during ploughing in 1977, directly above a burial cairn covering an extended inhumation (CloseBrooks 1980: 328). Two radiocarbon dates obtained at the time of the excavation suggested a later first-millennium $\mathrm{AD}$ date for the burial, but the determinations were of a low precision (Table S2).

One symbol-bearing object has been directly dated previously: an ox phalange with two symbols - a crescent and V-rod, and a mirror case-from the Broch of Burrian, Orkney, which provided a radiocarbon date [UB-6923] of cal AD 570-655 at 95\% probability (Clarke \& Heald 2008). Few other organic objects are available for direct dating, but another ox phalange decorated with a crescent and $\mathrm{V}$-rod and a rectangular symbol was found at the multi-period settlement at Pool, Sanday, Orkney (Hunter et al. 2007: 509), and was sampled for radiocarbon dating in 2017 as part of the University of Aberdeen Northern Picts project, along with the other dates reported here (Figure $4 \&$ Table S3). Given the lack of absolute dates, any opportunity to add to the corpus is important, and new fieldwork by the Northern Picts project has also targeted sites in eastern Scotland for contextual dating evidence for the symbol system.

The simple designs found in caves and occasionally in other contexts, such as the stone 'plaques' found at Dunnicaer, Aberdeenshire, have been suggested as the earliest examples of the symbol system (e.g. Alcock 1996, 2003: 372; Henderson \& Henderson 2004: 171) (Figure 5). Recent fieldwork at Dunnicaer has explored the context of these stones. Dunnicaer is located on a precipitous sea stack, close to another stack site at Dunnottar, which features in a seventh-century Irish annalistic account as being a site under siege, suggesting that it was an important power centre (Fraser 2009: 214). The symbol-stones were discovered from 1819 onwards when stone was quarried from the stack. In 1832 a group of youths found the remains of a low stone wall on the stack, throwing a number of stones into the sea (Thomas 1858). Few people have visited Dunnicaer since the nineteenth century, but three seasons of fieldwork in 2015-2017 by the University of Aberdeen have identified the remains of this wall as a rampart on the southern and western edges of the stack (Figure 6). Little of the rampart survives, but excavation identified a number of facing stones and slots dug for timber beams. The fieldwork demonstrates that Dunnicaer was a promontory fort (matching Thomas's 1858 interpretation) with a timber-laced rampart and other enclosing works of the kind known from the Iron Age and first-millennium AD around the Scottish coasts. Alcock (1996) interpreted the site as the focus of pre-Christian cultic activity, but without any excavation of the site. The recent work has shown that the stack was much larger

(C) Antiquity Publications Ltd, 2018 

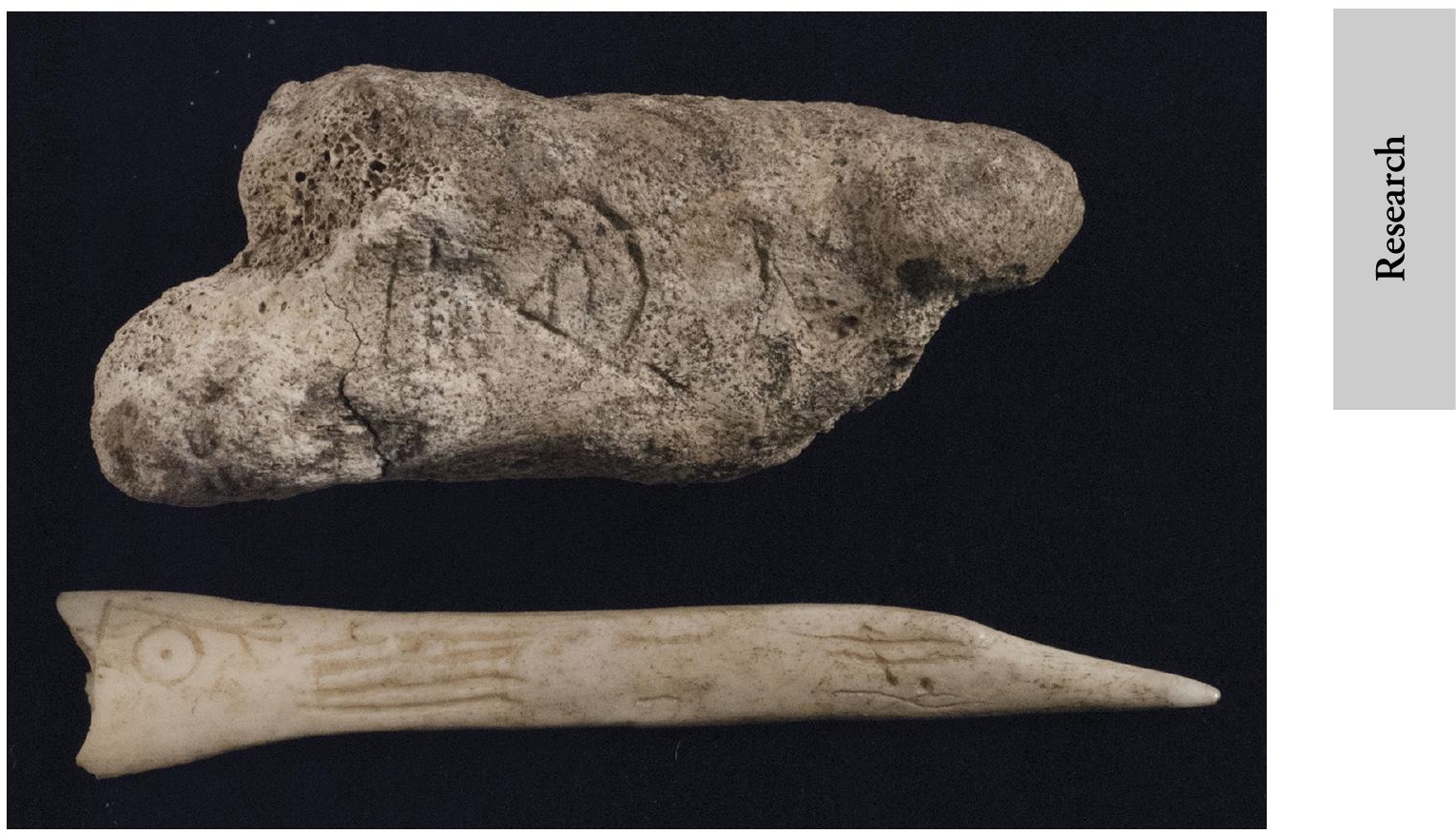

Figure 4. Ox phalange (above) decorated with double-disc, crescent and V-rod, and a bone pin (below) decorated with double-disc and Z-rod from Pool, Sanday, Orkney (C) Roderick Richmond for Orkney, Arts, Museums \& Heritage).

than survives today, with most of the site lost to severe coastal erosion. Inside the rampart, contemporaneous buildings and hearths have been identified (Figure 6). Finds included Roman Samian and black-burnished ware, glass from at least three vessels and a lead weight; all of which are rare imports this far north of the frontier, along with burnishing stones for metalworking.

Other excavations were carried out from 2012-2017 at Rhynie, also in Aberdeenshire. The excavations focused on an enclosure complex surrounding one in situ Pictish symbolstone (the Craw Stane) and the findspots of two others (Noble et al. 2013). The Craw Stane is a large monolith carved with a salmon and 'Pictish beast' symbol pair. The excavations revealed that the Craw Stane stood at the entrance of a high-status fortified site with imports from the Mediterranean and continental Europe (Noble et al. 2013) (Figure 7). A few metres from the Craw Stane, a stone socket, probably intended for another Pictish stone, was identified in 2015. This may have been the socket for the Rhynie Man stone, found downslope during ploughing in 1978.

\section{Radiocarbon dating and chronological modelling}

Radiocarbon dating and Bayesian modelling can provide refined and robust chronologies for the sites and objects highlighted above, as well as clearer chronologies for previously investigated sites and samples (Buck et al. 1996). Conventional radiocarbon ages (Stuiver \&

(C) Antiquity Publications Ltd, 2018 

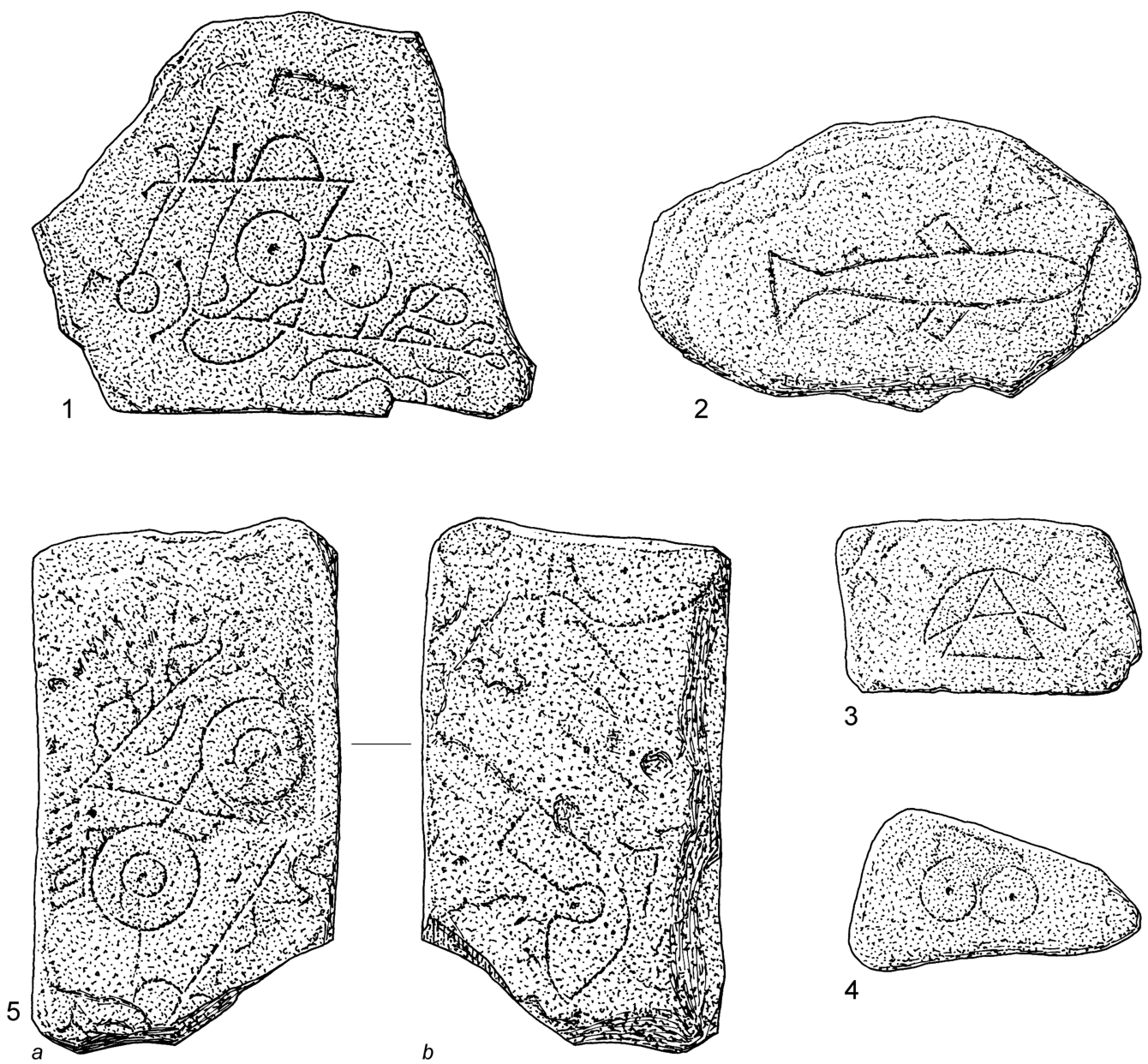

3

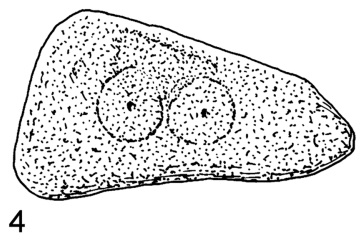

$1 \mathrm{~m}$

Figure 5. The five symbol stones from Dunnicaer. A sixth stone is also recorded but is of uncertain form (@) Historic Environment Scotland).

Polach 1977) are presented in the tables and the text, where they are quoted in accordance with the Trondheim convention (Stuiver \& Kra 1986). Calibrated date ranges were calculated using the internationally agreed calibration curve of Reimer $e$ t al. (2013) and OxCal v4.3 (Bronk Ramsey 1995, 1998, 2001, 2009). The date ranges have been calculated using the maximum intercept method (Stuiver \& Reimer 1986) and quoted with the endpoints rounded outward to 10 years. The probabilities shown in the figures were calculated using the method of Stuiver and Reimer (1993). Dating of the ox phalange from Pool (above) provides a date of cal AD 410-570 (95\% probability [SUERC-73735]; $1570 \pm 33 \mathrm{BP}$ ) (cal AD 420-540; 68\% probability). A bone pin from Pool, incised with another set of symbols (Figure 4), in this case a double-disc and Z-rod, was found in a (C) Antiquity Publications Ltd, 2018 


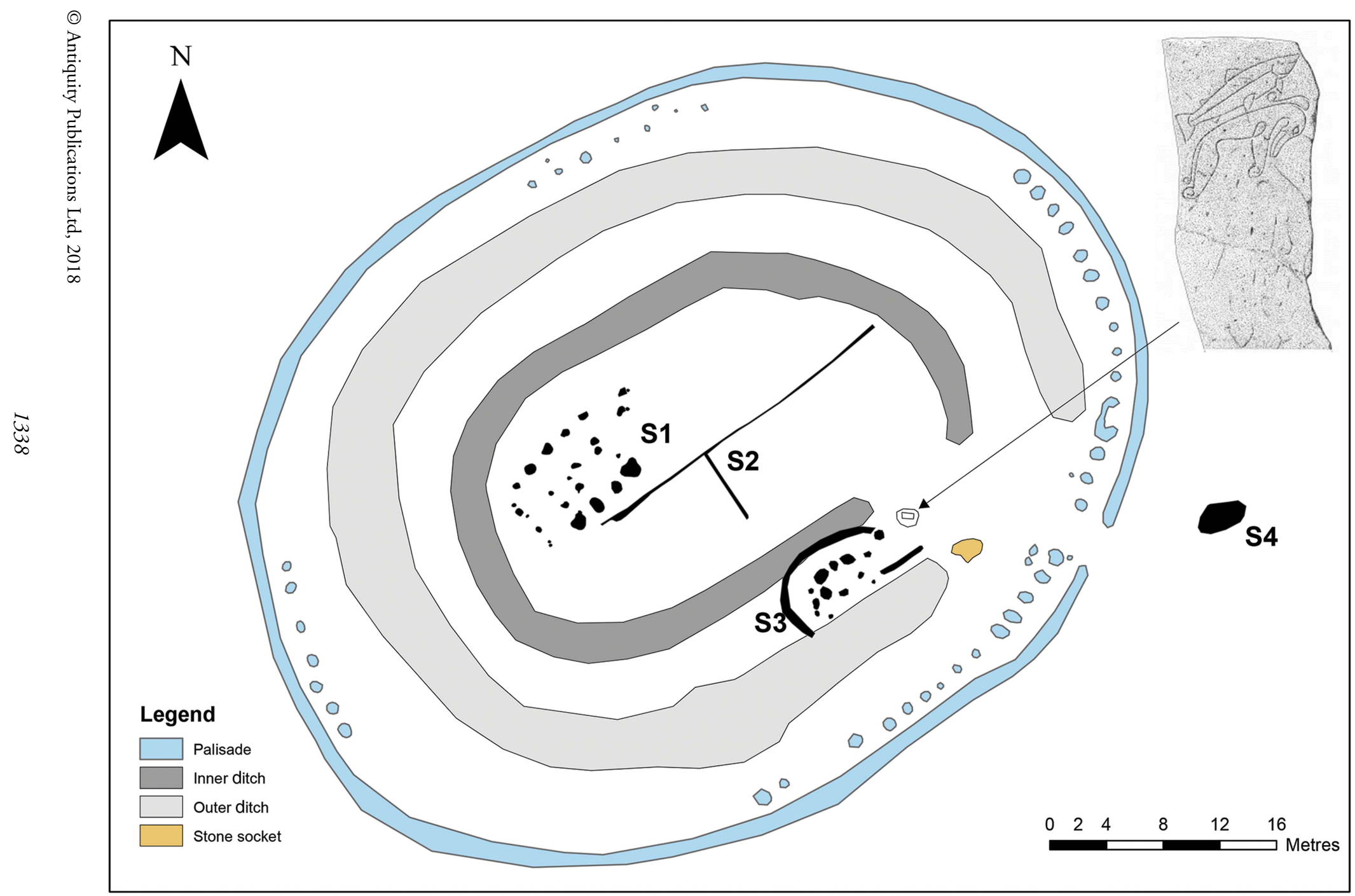

Figure 7. Groundplan of the Rhynie high-status enclosure complex with the Craw Stane, stone socket and associated buildings (S1-4) indicated. 
settlement layer (phase 6.4), the date of which can be constrained by modelling the available radiocarbon dates (Table S3). A simple Bayesian model that brings together the existing radiocarbon results into an unordered group of related activity estimates that phase 6.4 dates to cal AD 325-645 (95\% probability; GU-2243), and probably cal AD 425-575 (68\% probability), broadly contemporaneous with the directly dated ox phalange. The human remains from Dairy Park have also been re-dated by the Northern Picts project, showing that this burial, found in association with a symbol-stone, probably dates to cal AD 565-640 (95\% probability [SUERC-76203]; 1465 $\pm 17 \mathrm{BP}$ ) (cal AD 575-625; 68\% probability), broadly contemporaneous with the direct date from the Broch of Burrian ox phalange.

From Dunnicaer, single-entity, short-lived roundwood charcoal recovered from the rampart and settlement features of the promontory fort (Table S4) have been incorporated into a Bayesian model in an unordered group to provide an overall site chronology (Stuiver \& Reimer 1993; Bronk Ramsey 1995, 1998, 2001, 2009; Reimer et al. 2013; Hamilton \& Kenney 2015). The model shows good agreement $\left(\mathrm{A}_{\text {model }}=84\right)$, and estimates a start date of cal AD 55-235 cal AD for Dunnicaer (95\% probability; Figure 8; start: Dunnicaer), and probably cal AD 130-220 (68\% probability). The activity ended at the latest in cal AD 270 470 (95\% probability; Figure 8; end: Dunnicaer), and probably cal AD 345-425 (68\% probability) (Table S4). This broad chronology is supported by the artefactual evidence (Roman pottery and glass), which suggests a second- to fourth-century AD date for the use of the site. There are four dates that can be specifically related to the rampart with which the symbol-stones were associated (Table S4). Using the latest probability from this group (calculated in the model by the Last parameter in OxCal), suggests that the wall was constructed in cal AD 250-400 (95\% probability; Figure 8; build: timber wall), and probably in cal AD 285-350 (68\% probability).

A total of 35 radiocarbon dates are available for the enclosure complex at Rhynie. These account for all phases and major structural components, including the probable socket for the Rhynie Man stone. The chronological model and dates for Rhynie are presented in detail in Noble et al. (forthcoming), with the modelled probabilities summarised here. The model shows that activity at Rhynie began in cal AD 330-390 (95\% probability; Figure 8; start: Rhynie), and probably in cal $A D 355-380$ (68\% probability). Dated activity ended in cal $A D$ 480-570 (95\% probability; Figure 8; end: Rhynie), and probably in cal AD 510-560 (68\% probability). The material culture typologies strongly support the radiocarbon ranges, with no evidence for use of the site after the mid sixth century AD.

\section{The origins of the Pictish symbol system}

Of course, none of the dates modelled here can directly establish the date at which the stones were carved. The dates from Dunnicaer relate to the wall and not the carved stones themselves, but the antiquarian accounts make it clear that the latter were found in association with a wall built along the edge of the stack. Indeed, several of the Dunnicaer symbol-stones have been interpreted as 'plaques' that were suitable for being set into a rampart (e.g. Alcock \& Alcock 1992: 282; Alcock 1996, 2003). The stone wall mentioned at the time of the stones' discovery, and into which they were probably set, is dated on the basis of the recent fieldwork to cal AD 285-350. None of the other dated activity on the stack 


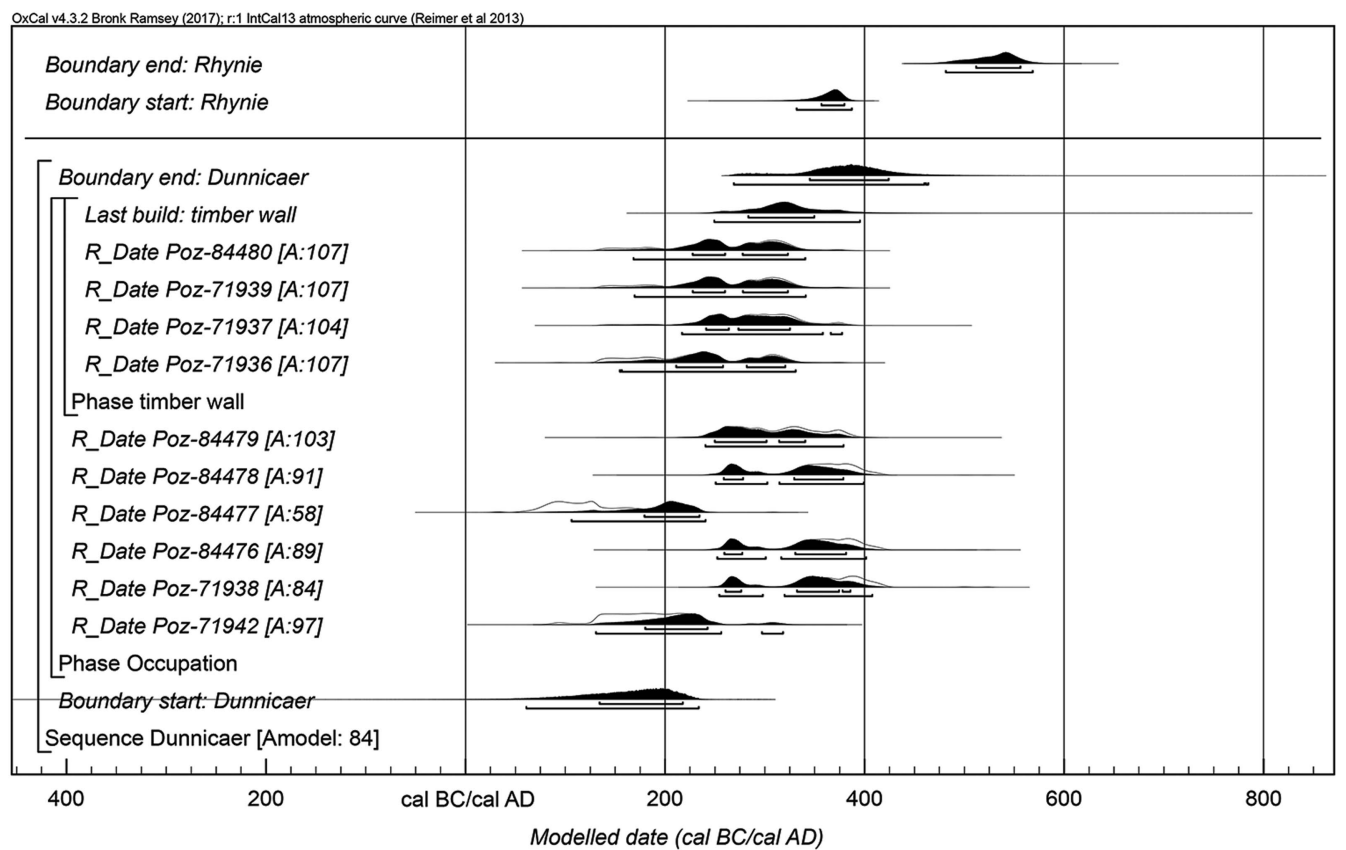

Figure 8. Chronological model for Dunnicaer and modelled start and end dates for Rhynie. Each distribution represents the relative probability of an archaeological event. The distributions in outline show the calibration of each result by the probability method (Stuiver \& Reimer 1993). The solid distributions are posterior density estimates derived from the chronological model.

diverges significantly from the construction date for the rampart, and the material culture fits comfortably into that bracket.

While the symbol-stones were damaged as a result of the circumstances of their discovery and re-use in the nineteenth century, they appear to be largely intact. Dunnicaer 5 has carvings on both sides that may belong to different phases of carving, but there was also extensive remodelling of the site and settlement, with an earlier phase of rampart and multiple overlapping dwellings. None of the dates or stratigraphy suggests later activity unconnected to the fortified settlement. There is, thus, a strong argument for the symbolstones being contemporaneous with the promontory fort, which provides the best evidence to date for the carving of symbols within a Roman Iron Age context-in this case in association with a high-status coastal settlement.

The early dating from Dunnicaer sheds new light on other sites with similar styles of carving, such as cave sites. Carvings from Sculptor's Cave, Covesea, Moray, with simple, small-scale designs (including a fish, crescents and V-rods, mirror-cases, a triple-oval and a 'flower' symbol) are similar in style to the Dunnicaer carvings. From inside the cave, other than modern finds (including an undiagnostic iron rivet misidentified as 'Viking'), none of the material culture suggests activity later than the fourth century AD. A collection of human remains provides evidence for the practice of decapitation between cal AD 220-335 (Armit et al. 2011: 276), and there is also an important assemblage of Roman coins, metalwork and pottery, with the latest coin dating to AD 365 (Armit et al. 2011: 259). These dates are

(C) Antiquity Publications Ltd, 2018 
broadly contemporaneous with the construction of the wall at Dunnicaer. There are also Pictish symbols carved in a number of caves at East Wemyss, Fife. Very few in situ deposits have been found during excavations at the caves, but one cave, the Sliding Cave (which has carvings of a double-disc, serpents and a comb case on the walls of the cave interior), was found to have an intact floor layer (with no evidence of later use) dated to cal AD 240-390 (95\% probability [NZA-20755]; 1726 $\pm 30 \mathrm{BP}$ ), again broadly contemporaneous with the dates from Dunnicaer (Gibson \& Stevens 2007).

Individually, and because they are associated and not direct dates, any one of these sites alone would be deemed insufficient evidence to support the early dating for these simple examples of the Pictish symbol system. When considered together, however, the fact that the symbols at all three sites had previously been stylistically linked, and that all three have since produced very similar chronological ranges for activities during the third to fourth centuries $\mathrm{AD}$, increases confidence in these early associated dates from the Scottish mainland. Forsyth (1997: 93) suggested that the Dunnicaer and cave symbols were 'cursive', and thus their form may not relate to date, but the available dating evidence suggests that they are indeed early examples.

\section{An outline chronology and complementary typology}

Using the range of associated and direct dates presented here, we suggest a new and more robust outline chronology for the Pictish symbols: the evidence from Dunnicaer and the cave sites suggest that unelaborated carvings, generally of a smaller size and less standardised when compared with the later standing stone monuments, probably originated in the third to fourth centuries AD. The larger standing stone monuments in eastern Scotland were set up in the period from the late fourth to the early sixth century $\mathrm{AD}$, and the dated evidence includes a detailed chronology for Rhynie that incorporates dates from a probable stone socket. The dated examples from settlements in Orkney show symbol use in the most northerly parts of Pictland from as early as the fifth century $\mathrm{AD}$, and certainly by the early sixth century. At Dairy Park, Dunrobin, doubt has been cast over the association between the symbol-stone and cairn (Clarke 2007: 27), but the stone was found directly over the cairn when the field was ploughed for the first time (Close-Brooks 1980: 330). The burial has now been dated with high precision to cal AD 575-625.

This outline chronology also supports a new typology (developed by Goldberg and to be published in the near future). Examining the style of the symbols from the dated sites shows that relatively plain, small-scale symbols were present at Dunnicaer, Pool and the cave sites. A relatively plain, but clear, linear style is also consistent across the cluster of symbol-stones at Rhynie. This contrasts with the more elaborate symbols at Dairy Park, and at a minute scale, the carefully depicted internal elaboration of the crescent and V-rod found on the ox phalange from the Broch of Burrian, Orkney, both of which have produced dates from the late sixth or early seventh century $\mathrm{AD}$. The typology proposes changing conventions in symbol form that may be chronologically sensitive (for similar analysis, see Thickpenny (2012: 10-16)), and that are largely confirmed in light of this new dating evidence. For example, single-sided combs are only shown on Class I stones, and tend to be depicted in 
plain linear style, whereas only double-sided combs are shown on Class II (Christian) monuments (Figure 9). Using our dated examples, the fifth- to sixth-century symbol-stones from Rhynie only have single-sided combs and a clear linear style of carving (Figure 9c-e), whereas Class I stones with double-sided combs often accompany more elaborative carving techniques, and date closer to the Christian monuments of the seventh to eighth centuries $\mathrm{AD}$, as with the sixth- to seventh-century dated example from Dairy Park (Figure 9f).

There also appears to be a general trend towards larger monuments over time. The doubledisc symbols from Dunnicaer, for example, are amongst the smallest in the symbol-stone corpus. Rhynie includes a stone (Rhynie 8), that, although truncated, shows symbols of a scale that indicate it was always a modest monument of a similar character and size to the Dunnicaer plaques. It is, perhaps, telling that this stone has a symbol that only otherwise appears at the Sculptor's Cave. With the cave symbols probably of an early date, these parallels in the form, size and style of symbol seen on Rhynie 8 bring together many of the strands of evidence here.

Previous art-historical analysis had suggested that the most complex designs were the earliest, based on the idea that there was a 'master' carver and symbol, and that these designs tended to simplify or break down over time (Stevenson 1955: 102-103). The complementary absolute dating and typological scheme outlined here suggest that symbols without significant internal elaboration, of the style found on the Dunnicaer 'plaques', in the caves and on some of the Rhynie monuments, are probably earlier in the sequence, while monuments with symbols that show elaborate internal decoration are probably later, of sixth- to early seventh-century $\mathrm{AD}$ date, based on the complementary dating of the Broch of Burrian ox phalange and the burial at Dairy Park (Figure 9). Almost all of the symbols on Class II cross-slabs are even more elaborate in the range of motifs employed, using an international repertoire of decoration shared widely in the Early Christian world, but with a particular 'Insular' style that shares similarities with contemporaneous monuments across Britain and Ireland (Henderson \& Henderson 2004; Goldberg 2015). An eighth-century high point for the larger cross-slabs is probable, such as those with prominent relief-carved symbols from the monastery at Portmahomack (Carver et al. 2016: 167) and from the Tarbat peninsula. The symbol system appears to have come to an end during the ninth- to tenth-century $\mathrm{AD}$ ascendancy of the kingdom of Alba, when a new language and new lineages began to dominate elite power structures in eastern and northern Scotland (Woolf 2007: 312).

\section{Interpreting the symbols}

The new dates strongly suggest that the Pictish symbol system originated earlier than is often countenanced, and did so in a context that makes contact with the Roman world a probable factor in their origin. In the third and fourth centuries $\mathrm{AD}$, raiding, trading and diplomatic gifts and bribes shaped imperial contact and social change in eastern Scotland (Hunter 2007; Blackwell et al. 2017), and it is in this context that the idea of a written script may have emerged. In this respect, the symbols appeared in a similar context and chronological horizon to other epigraphic systems in North-west Europe. In Scandinavia, the use of runes has been

(C) Antiquity Publications Ltd, 2018 
(a)

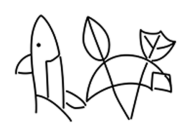

(f)

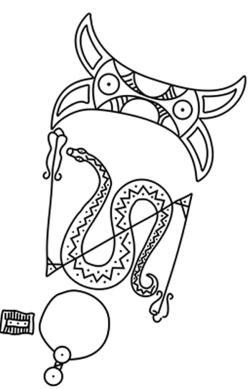

(b)

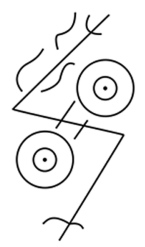

(g)

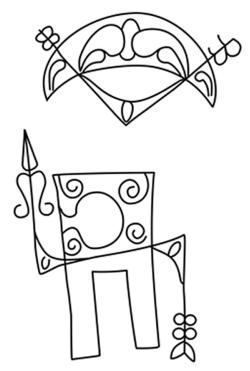

(c)

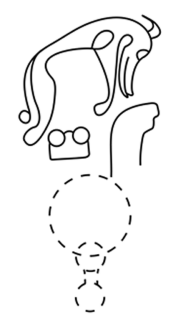

(h)

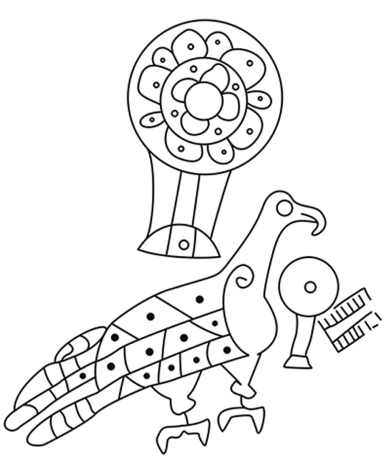

(d)

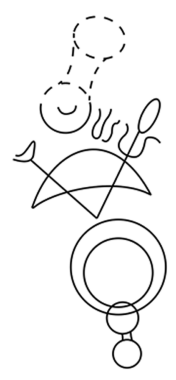

(i)

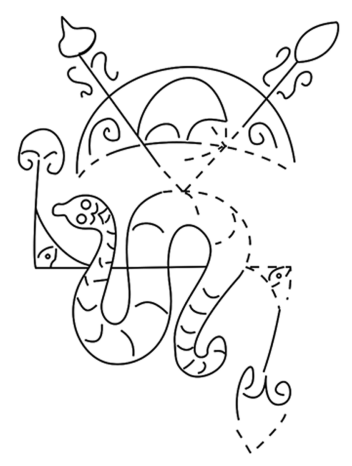

(e)

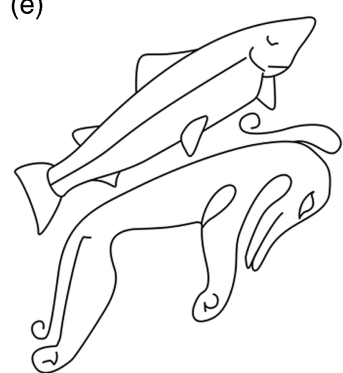

(j)

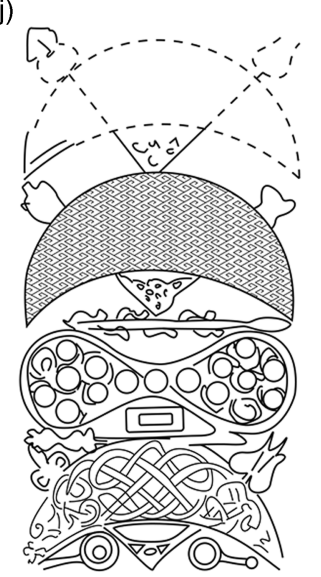

Figure 9. Symbol typology. The earlier examples, a) Sculptor's Cave, Covesea; b) Dunnicaer; c) Rhynie 8; and d) Rhynie 6, show symbols only in outline with single-sided mbs and no internal elaboration of the symbols. They are also modest in scale. The more monumental examples may be from later, such as e) the Craw Stane, Rhynie 1 . The Dairy Park, Dunrobin example $(f)$ is likely to be late sixth to early seventh century AD in date and broadly contemporaneous with other examples showing decorative elaboration to the symbols (e.g. $g, h$ and $i$ : Ballintomb, Inveravon, Brandsbutt). The last phase of symbols are on Class II monuments with very obvious references to manuscript art in their decorative styles, which include interlace, raised bosses, peltae designs and key pattern, often carved in relief, e.g. (j) Rosemarkie.

\section{Research}


traced back to the second century AD, with their use probably influenced by the Greek alphabet and its Etruscan and Roman derivatives, and the runic system created by people with experience of Mediterranean language, including reading and writing traditions (Odenstedt 1990: 169; Barnes 2012: 10-11; Findell 2014: 15). The dating of ogham in Ireland has been largely based on linguistic archaisms and innovations, with few inscribed objects directly dated (Swift 1997: 54). Traditional dating schemes based on epigraphic styles have suggested a fifth-century start date (Jackson 1950, 1953; Nash-Williams 1950), but earlier origins in the second or third century AD have also been posited (Ahlqvist 1982: 810; Harvey 1987: 9). An ogham inscription amongst the votive offerings from the later phases of deposition at Newgrange, including a medallion of Emperor Constantine II, may date to as early as the fourth century AD (Charles-Edwards 2013: 119). Recent radiocarbon by the National Museum Scotland dating of an ogham-inscribed knife-handle from the Broch of Gurness in Orkney shows that ogham was also known in the far north of Scotland by cal AD 340-540 (95\% probability [SUERC-30669]; 1625 $\pm 35 \mathrm{BP}$ ), in a phase that also includes small unelaborated symbol-stones, like those from Pool. An ogham inscription from Silchester in southern England has also been dated to the fourth or fifth century in a context in which Roman inspiration is highly likely (Fulford et al. 2000: 17; see also Swift 1997: 49).

As with runes and ogham, the Pictish symbols were also probably created beyond the frontier in response to Roman literacy, but as with Irish and Germanic groups, the Picts did not directly adopt the alphabet - they invented their own system, albeit a non-alphabetic one. Nonetheless, in all three cases the script innovators imitated the literate cultures of Rome, but in ways that at least partly "proclaimed an independence" from the Mediterranean world (Barnes 2012: 11).

Whatever the origins of these epigraphic systems, the roles of runic, ogham and Pictish symbols were clearly multiple. A number of ogham inscriptions expressed lineage, and others may have been memorials, while still others were concerned with boundaries and landholding, and early forms of runes appear to have had a similar variety of roles (Swift 1997: 44; Barnes 2012: 11; Bhreathnach 2014: 42-44). The main purpose of Pictish symbols seems to be to communicate identities, most probably names, and where well contextualised, they often appear in high-status contexts, such as Rhynie, or on elite objects such as the massive silver chains or the silver plaque from Norrie's Law (Blackwell et al. 2017: 101). The Dunnicaer site includes extremely rare Roman imports for north-east Scotland, and enclosed sites are very unusual for this period. While at first glance the cave sites seem difficult to reconcile with highstatus activity, the Roman material from Covesea is also exceptional for this period and region; moreover, the contemporaneous human remains at Covesea have been interpreted as beheadings in the Roman style of what may have been native elites (Armit et al. 2011: 276). Given the context of use for these early dated symbols, it may be that Pictish symbols operated like early hieroglyphs in Egypt, which evolved as a public form of display concerned with prestige and high-status identities and activities (Baines 1995: 471).

Recent scholarship has suggested that Pictish ethnogenesis was brief and late, a phenomena of the seventh century AD (Fraser 2009: 43-67; Woolf 2017). Writing, however, has long been linked to the development of more complex societies in a variety of contexts around the world (e.g. Postgate et al. 1995: 459), and the development of the Pictish symbols from possibly as early as the third century $\mathrm{AD}$ seems to coincide with the new social

(C) Antiquity Publications Ltd, 2018 
and political identities evident in late Roman sources and with broad changes in the archaeological record (Hunter 2007: 42-44). The shared use of this symbolic script across eastern and northern Scotland by the fifth century is in precisely the areas that seventh- and eighth-century historical sources locate the Pictish kingdoms. Once introduced, the symbol system would have had important social consequences allowing names and perhaps lineages to be transmitted across space and time and communicated within a distinct social milieu (Goody 1968: 4; Driscoll 1988; Innes 1998: 3). This would have had particular implications for long-term memory transmission, with the recording in stone of elite names perhaps helping to underscore inter-generational rights and wider group identities.

\section{Conclusions}

Previous dating of the Pictish symbol system has largely relied on art-historical analysis, but it is only through scientific dating that more robust chronologies can be constructed. The dating and typology outlined here suggest that interaction with the Roman world probably provided the context for the development of the symbol system. Establishing an outline chronology through a combination of direct dating, Bayesian modelling of associated dates from archaeological excavation, and the combining of typological and contextual methods can help us to rewrite the history of these symbolic traditions of Northern Europe, and to understand more clearly the context of their development and use.

\section{Acknowledgements}

Thanks go to Gail Drinkall (Orkney Museum) and our funders: Aberdeenshire Council Archaeology Service, Historic Environment Scotland, The Strathmartine Trust and the University of Aberdeen Development Trust. Isabel Henderson helped to refine Table 1. Fraser Hunter and Alice Blackwell read and commented on an earlier draft. The writing of this article was also supported by a Leverhulme Trust Research Leadership Award (RL-2016-069).

\section{Supplementary material}

To view supplementary material for this article, please visit https://doi.org/10.15184/aqy.2018.68

\section{References}

AHLQvist, A. 1982. The early Irish linguist: an edition of the canonical part of the Auraicept na nEces. Helsinki: Societas Scientiarum Fennica.

Alcock, L. 1996. Ur-symbols in the Pictographsystem of the Picts. Pictish Arts Society 9: 2-5.

-2003 . Kings and warriors, craftsmen and priests in northern Britain AD 550-850. Edinburgh: Society of Antiquaries of Scotland.

Alcock, L. \& E.A. Alcock. 1992. Reconnaissance excavations on Early Historic fortifications and other royal sites in Scotland, 1974-84.

Proceedings of the Society of Antiquaries of Scotland 122: 215-827.
Allen, R.J. \& J. Anderson, J. 1903 [1993]. The Early Christian monuments of Scotland. Balgavies: Pinkfoot.

Armit, I., R.J. Schulting, C.J. Knüsel \& I.A.G. Shepherd. 2011. Death, decapitation and display: the Bronze and Iron Age human remains from the Sculptor's Cave, Covesea, northeast Scotland. Proceedings of the Prehistoric Society 77: 251-78. https://doi.org/10.1017/S0079497X00000694

BAINES, J. 1995. Communication and display: the integration of early Egyptian art and writing. Antiquity 63: 471-82. https://doi.org/10.1017/S0003598X00076444

BARNES, M.P. 2012. Runes: a handbook. Woodbridge: Boydell. 
Bhreathnach, E. 2014. Ireland in the medieval world: AD 400-1000. Dublin: Four Courts.

Blackwell, A., M. Goldberg \& F. Hunter. 2017. Scotland's early silver. Edinburgh: National Museums Scotland.

Bronk Ramsey, C. 1995. Radiocarbon calibration and analysis of stratigraphy. Radiocarbon 37: 425-30. https://doi.org/10.1017/S0033822200030903

- 1998. Probability and dating. Radiocarbon 40: 461-74.

-2001. Development of the radiocarbon calibration program. Radiocarbon 43: 355-63.

https://doi.org/10.1017/S00338222000 38212

- 2009. Bayesian analysis of radiocarbon dates. Radiocarbon 51: 337-60. https://doi.org/10.1017/S0033822200033865

Buck, C.E., W.G. Cavanagh \& C.D. Litton. 1996. Bayesian approach to interpreting archaeological data. Chichester: John Wiley \& Sons.

Carver, M., J. Garner-Lahire \& C. Spall. 2016. Portmahomack on Tarbat Ness: changing ideologies in north-east Scotland, sixth to sixteenth century $A D$. Edinburgh: Society of Antiquaries.

Charles-Edwards, T.M. 2013. Wales and the Britons, 350-1064. Oxford: Oxford University Press.

Clarke, D.V. 2007. Reading the multiple lives of Pictish symbol stones. Medieval Archaeology 51: 19-39. https://doi.org/10.1179/174581707x224642

Clarke, D.V. \& A. Heald. 2008. A new date for 'Pictish' symbols. Medieval Archaeology 52: 291-310.

Close-Brooks, J. 1980. Excavations in the Dairy Park, Dunrobin, Sutherland, 1977. Proceedings of the Society of Antiquaries of Scotland 110: 328-45.

Diack, F.C. 1944. The inscriptions of Pictland. Aberdeen: Spalding Club.

Driscoll, S.T. 1988. Power and authority in Early Historic Scotland: Pictish symbol stones and other documents, in J. Gledhill, B. Bender \& M.T. Larsen (ed.) State and society: the emergence and development of social hierarchy and political centralization: 215-36. London: Taylor \& Francis.
- 2011. Pictish archaeology: persistent problems and structural solutions, in S.T. Driscoll, J. Geddes \& M. Hall (ed.) Pictish progress: 245-80. Leiden: Brill.

Earl of Southesk. 1893. Origins of Pictish symbolism. Edinburgh: David Douglas.

Findell, M. 2014. Runes. London: British Museum.

Forsyth, K. 1997. Some thoughts on Pictish symbols as a formal writing system, in I. Henderson \& D. Henry (ed.) The worm, the germ and the thorn: 85-98. Brechin: Pinkfoot.

Foster, S. 2014. Picts, Gaels and Scots: Early Historic Scotland. Edinburgh: Birlinn.

Fraser, J.E. 2009. From Caledonia to Pictland: Scotland to 795. Edinburgh: Edinburgh University Press. https://doi.org/10.3366/edinburgh/ 9780748612314.001 .0001

Fulford, M., M. Handley \& A. Clarke. 2000. An early date for ogham: the Silchester ogham stone rehabilitated. Medieval Archaeology 44: $1-23$. https://doi.org/10.1179/med.2000.44.1.1

Gibson, C. \& C. Stevens. 2007. Iron Age and Pictish activity at Wemyss Caves, Fife. Tayside and Fife Archaeological Journal 13: 91-99.

Goldberg, M. 2015. At the Western edge of the Christian world, c. AD 600-90, in J. Farley \& F. Hunter (ed.) Celts: art and identity: 172-205. London: British Museum.

Goody, J, 1968. Introduction, in J. Goody (ed.) Literacy in traditional societies: 1-26. Cambridge: Cambridge University Press.

Hamilton, D. \& J. Kenney. 2015. Multiple Bayesian modelling approaches at Ysgol yr Hendre, Caernarfon, north Wales. Quaternary Geochronology 25: 72-82. https://doi.org/10.1016/j.quageo.2014.10.001

Harvey, A. 1987. Early literacy in Ireland: the evidence from ogham. Cambridge Medieval Celtic Studies 14: 1-15.

Henderson, I. 1967. The Picts. London: Thames \& Hudson.

Henderson, G. \& I. Henderson. 2004. The art of the Picts: sculpture and metalwork in early medieval Scotland. London: Thames \& Hudson.

Hunter, F. 2007. Beyond the edge of the empire: Caledonians, Picts and Romans. Rosemarkie: Groam House. 
Hunter, J., A.N. Smith \& J. Bond. 2007. Investigations in Sanday, Orkney: excavations at Pool, Sanday. Kirkwall: Orcadian.

InNes, M. 1998. Memory, orality and literacy in an early medieval society. Oxford: Oxford University Press.

Jackson, A. 1984. The symbol stones of Scotland. Stromness: The Orkney Press.

JaCKSON, K.H. 1950. Notes on the ogham inscriptions of southern Britain, in C. Fox \& B. Dickins (ed.) The early cultures of Northwest Europe: 197-213. Cambridge: H.N. Chadwick Memorial Studies.

- 1953. Language and history in early Britain: a chronological survey of the Brittonic languages $1^{\text {st }}$ to $12^{\text {th }}$ century $A D$. Edinburgh: Edinburgh University Press.

LaInG, L. \& J. LaIng. 1984. The date and origin of the Pictish symbols. Proceedings of the Scottish Antiquaries Society 114: 261-76.

- 1993. The Picts and the Scots. Stroud: Alan Sutton.

LeE, R. 2010. The use of information theory to determine the language character type of Pictish symbols. Scottish Archaeological Journal 32: 137-76. https://doi.org/10.3366/saj.2010.0014

Lee, R., P. Jonathan \& P. Ziman. 2010. Pictish symbols revealed as a written language through application of Shannon entropy. Proceedings of the Royal Society 10: 1-16. https://doi.org/10.1098/rspa.2010.0041

Maск, A. 2007. Symbols and pictures: the Pictish legacy in stone. Brechin: Pinkfoot.

Nash-Williams, V.E. 1950. The Early Christian monuments of Wales. Cardiff: University of Wales.

Nixon, C.E.V., B.S. Rodgers \& R.A.B. Mynors (ed.). 1994. In praise of later Roman emperors: the Panegyrici Latini. Berkeley: University of California Press.

Noble, G., M. Gondek, E. Campbell \& M. Coок. 2013. Between prehistory and history: the archaeological detection of social change among the Picts. Antiquity 87: 1136-50. https://doi.org/10.1017/S0003598X00049917

Noble, G., M. Gondek, E. Campbell, N. Evans, D. Hamilton, A. Ross \& S. Taylor. Forthcoming. A powerful place of Pictland: interdisciplinary perspectives on a post-Roman power centre. Submitted to Medieval Archaeology.
Odenstedt, B. 1990. On the origin and early history of the runic script. Stockholm: Almqvist \& Wiksell.

Papdopoulos, J.K. 2016. The early history of the Greek alphabet: new evidence from Eretria and Methone. Antiquity 90: 1238-54. https://doi.org/10.15184/aqy.2016.160

Postgate, N., T. Wang \& T. Wilkinson. 1995. The evidence for early writing: utilitarian or ceremonial? Antiquity 69: 459-80. https://doi.org/10.1017/S0003598X00081874

RCAHMS. 2007. Pictish symbol stones: an illustrated gazeteer. Edinburgh: RCAHMS.

- 2008. The Pictish symbols of Scotland. Edinburgh: RCAHMS.

Reimer, P.J., E. Bard. A. Bayliss, J.W. Beck, P.G. Blackwell, C. Bronk Ramsey, C.E. Buck, H. Cheng, R.L. Edwards, M. Friedrich, P.M. Grootes, T.P. Guilderson, H. Haflidason, I. Hajdas, C. Hatté, T.J. Heaton, D.L. Hoffmann, A.G. Hogg, K.A. Hughen, K.F. Kaiser, B. Kromer, S.W. Manning, M. Niu, R.W. Reimer, D.A. Richards, E.M. Scott, J.R. Southon, R.A. StafF, C.S.M. Turney \& J. van DeR Plicht. 2013. IntCal13 and Marine13 radiocarbon age calibration curves $0-50,000$ years cal BP. Radiocarbon 55: 1869-87. https://doi.org/10.2458/azu_js_rc.55.16947

SAmson, R. 1992. The reinterpretation of the Pictish symbols. Journal of the British Archaeological Association 145: 29-65. https://doi.org/10.1179/jba.1992.145.1.29

Sproat, R. 2010. Ancient symbols, computational linguistics, and the reviewing practices of the general science journals. Computational Linguistics 36: 585-94. https://doi.org/10.1162/coli_a_00011

Stevenson, R.B.K. 1955. Pictish art, in F.T. Wainwright (ed.) The problem of the Picts: 97-128. Edinburgh: Thomas Nelson.

StUiver, M. \& R.S. KRA. 1986. Editorial comment. Radiocarbon 28(2B): ii. https://doi.org/10.1017/S003382220006015X

Stuiver, M. \& H.A. Polach. 1977. Reporting of ${ }^{14} \mathrm{C}$ data. Radiocarbon 19: 355-63. https://doi.org/10.1017/S0033822200003672

Stuiver, M. \& P.J. Reimer. 1986. A computer program for radiocarbon age calibration. Radiocarbon 28(2B): 1022-30. https://doi.org/10.1017/S0033822200060276 
- 1993. Extended ${ }^{14} \mathrm{C}$ data base and revised CALIB $3.0{ }^{14} \mathrm{C}$ calibration program. Radiocarbon 35 : 215-230. https://doi.org/10.1017/S0033822200013904

SwIFT, C. 1997. Ogham stones and the earliest Irish Christians. Maynooth: Department of Old Irish, National University of Ireland.

Thickpenny, C. 2012. Decorative minutiae in the Pictish social landscape. Unpublished MPhil essay, University of Glasgow. Available at: http://eprints.gla.ac.uk/148614/ (accessed 11 September 2018).

Thomas, A. 1858. Notice of sculptured stones found at 'Dinnacair', a rock in the sea, near Stonehaven. Proceedings of the Society of Antiquaries of Scotland 3: 69-75.
Thomas, C. 1961. The animal art of the Scottish Iron Age and its origins. The Archaeological Journal 117: 14-64. https://doi.org/10.1080/00665983.1961. 10854187

- 1963. The interpretation of the Pictish symbols. The Archaeological Journal 120: 31-64. https://doi.org/ 10.1080/00665983.1963.10854237

Wainwright, F.T (ed.). 1955. The Picts and the problem. The problem of the Picts: $1-53$. Edinburgh: Thomas Nelson.

Woolf, A. 2007. From Pictland to Alba, 789-1070. Edinburgh: Edinburgh University Press.

-2017. On the nature of the Picts. Scottish Historical Review XCVI (2): 214-17.

Received: 5 December 2017; Revised: 30 January 2018; Accepted: 2 March 2018

(C) Antiquity Publications Ltd, 2018 